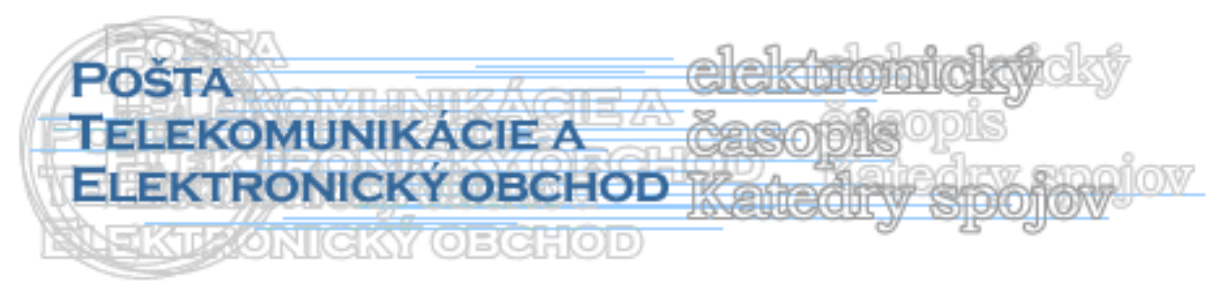

\title{
LIBERALIZACE EVROPSKÉHO POŠTOVNÍHO TRHU
}

\author{
Libor Švadlenka, Jan Roth*
}

\section{Úvod} vládního omezení.

Liberalizací se obecně rozumí uvolňování respektive zmírňování dosavadního

Liberalizace poštovního trhu tedy v souladu s výše uvedenou definicí znamená postupnou eliminaci dosavadního zvýhodněného postavení národních poštovních operátorů tak, aby se zde mohla plně uplatnit konkurence, která je všeobecně považována za prvek akcelerace pokroku a zvyšování kvality služeb.

První snahy o postupné uplatňování tržních sil a rozvoj konkurence v sektoru poštovních služeb byly iniciovány již v 80-tých let minulého století řadou nadnárodních poštovních operátorů, kteří logicky cítili v další redukci poštovních monopolů př́iležitost pro větší uplatnění na tomto trhu. Navíc požadavky tohoto druhu důrazně uplatňovala a stále uplatňuje také Světová obchodní organizace, která zásadně odmítá jakékoli omezení hospodářské soutěže.

\section{Postupný proces liberalizace v EU}

Postupná liberalizace evropského poštovního trhu je proces, pro jehož nastavení byla zásadním právním předpisem směrnice 97/67/EC, kde se poprvé definoval věcný, hmotnostní a cenový limit pro vyhrazené služby poskytovatelům univerzální služby. Tyto vyhrazené služby byly definovány jako sběr, třídění, přeprava a dodání zásilek s aktuálním sdělením vnitřního styku, jejichž cena je nižší než pětinásobek veřejného tarifu za zásilku s aktuálním sdělením prvního stupně hmotnosti nejrychlejší standardní kategorie, pokud váží méně než 350 g. V miřre nezbytné pro zachování univerzální poštovní služby mohly být přeshraniční zásilky a adresné reklamní zásilky v rámci uvedených limitů také vyhrazeny.

Přijetím směrnice 2002/39/EC, která je novelou směrnice 97/67/EC, byl učiněn další krok v procesu postupné liberalizace poštovního trhu EU. Tato směrnice stanovila věcné, hmotnostní a cenové limity:

- od 1. ledna 2003 na 100 gramů a trojnásobek veřejného tarifu za zásilku s písemností prvního stupně hmotnosti nejrychlejší standardní kategorie,

- $\quad$ od 1. ledna 2006 na 50 gramů a dva a půl násobek veřejného tarifu za zásilku s písemností prvního stupně hmotnosti nejrychlejší standardní kategorie.

Poslední důležitý krok postupné liberalizace poštovního trhu EU přišel s novou směrnicí 2008/6/EC. Tato směrnice obsahuje změny směřující k dotvoření plně liberalizovaného trhu

\footnotetext{
* Ing. Libor Švadlenka, Ph.D., Univerzita Pardubice, Dopravní fakulta Jana Pernera, Katedra dopravního managementu, marketingu a logistiky, Studentská 95, 53210 Pardubice, Tel.: 466036375, E-mail:

Libor.Svadlenka@upce.cz

* Ing. Jan Roth, Česká pošta, s.p., Sekce řízení poštovní přepravy, Politických Vězňů 909/4, 11500 Praha 1,

Tel.: 221132 467, E-mail: Roth.Jan@cpost.cz.
} 
v rámci všech států EU. Nejdůležitějším bodem směrnice bylo stanovení termínu otevření poštovního trhu členských zemí EU, a to na 1 . ledna 2011 a pro státy s výjimkou na 1 . ledna 2013.

\section{Postupný proces liberalizace $\mathrm{v}$ ČR}

Pro postupný proces liberalizace poštovních služeb v ČR byl velmi důležitý zákon č. 29/2000 Sb., který stanovil hmotnostní limit poštovní výhrady pro provozovatele univerzální poštovní služby na 350 gramů. Neméně důležité bylo z tohoto zákona vyplývající nařízení vlády ČR č. 112/2000 Sb., které stanovilo cenové limity na pětinásobek ceny tehdejšího základního tarifu (ve vnitrostátním styku 27,- Kč a v mezinárodním styku 45,- Kč). Tyto limity byly reakcí na evropské právo, a tím byl učiněn krok pro pozdější vstup do EU.

Váhové i cenové limity se pak v ČR snižovaly ještě dvakrát:

- od 1. května 2004 na 100 gramů a 19,- Kč (nařízení vlády č. 305/2003 Sb.),

- $\quad$ od 1. ledna 2006 na 50 gramů a 18,- Kč (nařízení vlády č. 512/2005 Sb.).

Ve výše jmenovaných dvou př́ípadech byl hmotnostní limit stanoven nařízením vlády (oproti původnímu stanovení zákonem), aby bylo jednodušší váhové i cenové limity změnit. Další změnou bylo sjednocení cenového limitu z dřívějších dvou (vnitrostátní a mezinárodní) na jeden.

\section{Současný stav liberalizace v Evropě}

Jak už bylo výše řečeno, podle směrnice 2008/6/EC by se měl evropský poštovní trh otevř́t k 1. lednu 2011. Výjimka by se měla týkat 11 členských zemí (Česká republika, Kypr, Litva, Lotyšsko, Lucembursko, Mad'arsko, Malta, Polsko, Rumunsko, Řecko a Slovensko). Na základě ustanovení této směrnice měla být o využití odkladu vyrozuměna Evropská komise do 27. srpna 2008.

Z tab. 1 je zřejmé, že v současné době je již poštovní trh plně liberalizován ve Švédsku (1993), Finsku (1994), Spojeném království (2006) a v Německu (2008). V Estonsku, kde už v minulosti plně liberalizovaný trh byl, se před lety vrátili k poštovní výhradě v podobě hmotnostního limitu $50 \mathrm{~g}$ u některých zásilek. V několika dalších zemích už je univerzální poštovní služba redukována nad rámec podmínek vyplývajících $\mathrm{z}$ právních předpisů EU. Poštovní monopol měl být od 1. ledna 2008 zrušen i v Nizozemí, ale nestalo se tak. V záměru nizozemské vlády ale je liberalizovat trh dříve než v roce 2011, podle posledních zpráv dokonce již 1. dubna 2009. Národní poštovní operátor TNT Post je podle svých slov prripraven.

Poštovní trh ČR by se měl liberalizovat od 1. ledna 2013. Váhové i cenové limity pro vyhrazené poštovní služby budou zrušeny a současný národní poštovní operátor (Česká pošta, s. p.) přijde o poštovní monopol. Trh poštovních služeb se tak plně otevře konkurenci. 
Tab. 1 - Národní poštovní operátoři, stav liberalizace a vyhrazené služby ke dni 1. ledna 2009

\begin{tabular}{|c|c|c|c|c|c|c|c|}
\hline \multirow{2}{*}{ členská země EU } & \multirow{2}{*}{$\begin{array}{l}\text { národní poštovní } \\
\text { operátor }\end{array}$} & \multirow{2}{*}{$\begin{array}{c}\text { plně } \\
\text { liberalizováno }\end{array}$} & \multirow{2}{*}{$\begin{array}{l}\text { plánovaná } \\
\text { liberalizace }\end{array}$} & \multicolumn{4}{|c|}{ vyhrazené služby } \\
\hline & & & & $\begin{array}{c}\text { váha } \\
\text { (gramy) }\end{array}$ & $\begin{array}{c}\text { cena } \\
\text { (násobek) }\end{array}$ & $\begin{array}{c}\text { direct } \\
\text { mail }\end{array}$ & $\begin{array}{c}\text { přeshraniční } \\
\text { pošta }\end{array}$ \\
\hline Belgie & La Poste & - & 2011 & 50 & 2,5 & ano & ano \\
\hline Bulharsko & Bulgarian Posts & - & 2011 & 50 & 2,5 & ne & ano \\
\hline Česká republika & Česká pošta & - & 2013 & 50 & 2,5 & ne & ne \\
\hline Dánsko & Post Danmark & - & 2011 & 50 & 2,5 & ano & ano \\
\hline Estonsko & Eesti Post & - & 2011 & 50 & 2,5 & ne & ne \\
\hline Finsko & Posti & 1994 & - & - & - & - & - \\
\hline Francie & La Poste & - & 2011 & 50 & 2,5 & ano & ano \\
\hline Irsko & An Post & - & 2011 & 50 & 2,5 & ano & ano \\
\hline Itálie & Poste Italiane & - & 2011 & 50 & 2,5 & ne & ano \\
\hline Kypr & Cyprus Post & - & 2013 & 50 & 2,5 & ano & ano \\
\hline Litva & Lietuvos paštas & - & 2013 & 50 & 2,5 & ano & ano \\
\hline Lotyšsko & Latvijas Pasts & - & 2013 & 50 & 2,5 & ano & ano \\
\hline Lucembursko & P \& T Luxembourg & - & 2013 & 50 & 2,5 & ano & ano \\
\hline Mad'arsko & Magyar Posta & - & 2013 & 50 & 2,5 & ano & ano \\
\hline Malta & Maltapost & - & 2013 & 50 & 2,5 & ano & ano \\
\hline Nĕmecko & Deutsche Post & 2008 & - & - & - & - & - \\
\hline Nizozemsko & TNT & - & 2009 & 50 & 2,5 & ne & ne \\
\hline Polsko & Poczta POLSKA & - & 2013 & 50 & 2,5 & ano & ano \\
\hline Portugalsko & CTT & - & 2011 & 50 & 2,5 & ano & ano \\
\hline Rakousko & Österreichische Post & - & 2011 & 50 & 2,5 & ne & ne \\
\hline Rumunsko & Posta Romana & - & 2013 & 50 & 2,5 & ano & ano \\
\hline Řecko & ELTA - Hellenic Post & - & 2013 & 50 & 2,5 & ano & ano \\
\hline Slovensko & Slovenská pošta & - & 2013 & 50 & 2,5 & ano & ano \\
\hline Slovinsko & Posta Slovenije & - & 2011 & 50 & 2,5 & ne & ne \\
\hline Spojené království & Royal Mail & 2006 & - & - & - & - & - \\
\hline Španělsko & Correos & - & 2011 & 50 & 2,5 & ne & ano \\
\hline Švédsko & Posten & 1993 & - & - & - & - & - \\
\hline
\end{tabular}

Zdroj: LIJN, N. et al. Main developments in the European postal sector (2006 - 2008) - Final report. Ecorys [online]. 2008 [cit. 2009-02-22]. Dostupný z WWW: <http://ec.europa.eu/internal_market/post/doc/studies /2008-ecorys-final_en.pdf>.

\section{Dopad plné liberalizace na poštovní trh}

Předpokládanými pozitivními důsledky liberalizace poštovního trhu se obecně považují snížení cen, větší nabídka poštovních služeb a lepší kvalita nabízených poštovních služeb.

Dalším pozitivním efektem liberalizace trhu poštovních služeb je také fakt, že stávající národní poštovní operátoři budou nuceni $\mathrm{v}$ důsledku rostoucí konkurence na trhu zvyšovat svoji produktivitu a celkově se více zákaznicky orientovat.

$\mathrm{Na}$ druhou stranu nejvíce zmiňovaným rizikem spojeným s liberalizací poštovního trhu je problematika zajištění poskytování tzv. univerzální poštovní služby.

Úplnou liberalizací poštovního trhu, tj. zrušením poštovních monopolů se mohou národní poštovní operátoři v některých členských státech dostat do finančních potíží†, čímž by se také ohrozilo poskytování univerzální poštovní služby. Tato situace může nastat zejména v těch zemích, které nejsou na liberalizaci poštovního trhu připraveny a u kterých je malý počet zasílaných poštovních zásilek na jednoho obyvatele. V př́ípadě ČR jsou však obě tyto podmínky bohužel splněny, dokonce podle studie poradenské firmy

\footnotetext{
${ }^{\dagger}$ Lze totiž předpokládat, že konkurenti budou chtít poskytovat dosud vyhrazené služby přednostně v nízkonákladových oblastech (města), zatímco nákladově náročné oblasti (venkovské oblasti) pro ně nebudou atraktivní. Tento problém je obecně znám pod pojmem „cream skimming“, tj. lízání smetany.
} 
PricewaterhouseCoopers z roku 2006 se ČR umístila na předposledním místě v připravenosti na plné otevření poštovního trhu hned za posledním Rumunskem.

Dalším rizikem spojeným s liberalizací poštovního trhu je obava z rozsáhlé ztráty pracovních míst u stávajícího národního poštovního operátora jednak z titulu částečné ztráty trhu a také $z$ titulu nezbytné jeho restrukturalizace spojené s propouštěním neefektivních pracovníků. Tato obava je zcela legitimní, nicméně na druhou stranu přibudou pracovní místa u konkurenčních poštovních operátorů, čímž je toto riziko částečně eliminováno.

Celkově lze dopad liberalizace na oblast poštovních služeb přehledně charakterizovat prostřednictvím Obr. 1.

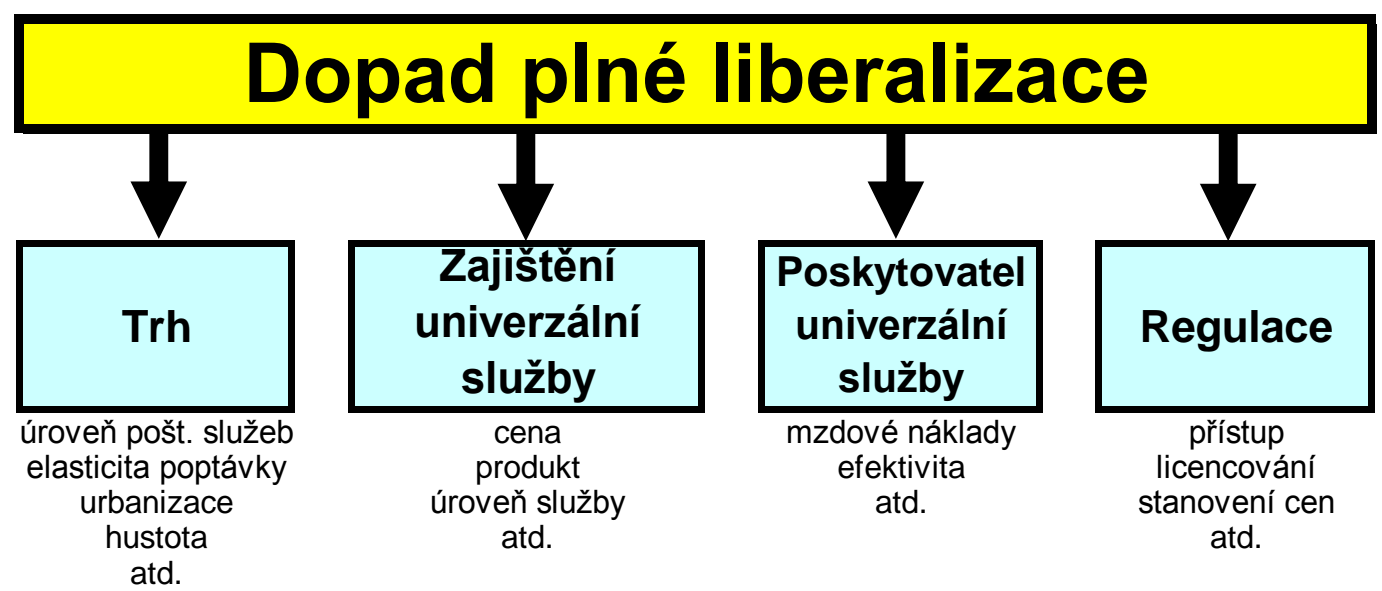

Obr. 1 - Dopad pIné liberalizace na jednotlivé segmenty poštovního trhu

\section{Financování univerzální služby v plně liberalizovaném trhu}

Pro poskytovatele univerzální služby a samožrejmě pro vlády jednotlivých členských států EU je v současnosti klíčovým problémem vyřešit financování univerzální služby v podmínkách plně liberalizovaného trhu. Podíváme-li se na způsoby financování všeobecně, nabízejí se tyto alternativy:

- Vyhrazená oblast - prostředky ze služeb vyhrazených poskytovateli univerzální služby,

- Státní dotace a výběrová řizení - prostředky ze státního rozpočtu,

- Kompenzační fondy různých druhi̊ - prostředky ze speciálně vytvořeného fondu,

- Ostatní segmenty - využití příjmů poskytovatele univerzální služby z jiných oblastí na poštovním trhu,

- Sdílení nákladi̊ - sdílení nákladů univerzální služby pomocí dohod s lokálními subjekty $\mathrm{v}$ jedné či více lokalitách.

Tyto způsoby ale nejsou pro evropský poštovní sektor všechny použitelné. V jednotlivých zemích EU prozatím převažuje způsob kompenzace nákladů za provoz univerzální služby pomocí vyhrazených služeb poskytovateli, s tím však nelze počítat v podmínkách plně liberalizovaného trhu. Dotace ze státního rozpočtu také nejsou ve většině členských zemí EU možné, protože jsou proti principu samofinancovatelnosti poštovních operátorů. Využití prŕíjmů operátora z jiných oblastí trhu, tzv. křížové financování, není akceptováno Evropskou komisí, tudíž je tento způsob v současné době také nepoužitelný. $\mathrm{V}$ plně liberalizovaném trhu $\mathrm{v}$ podstatě zbývají už jen kompenzační fondy a ty se zatím v Evropě moc neosvědčily.

\section{Liberalizace ve světě}

Univerzální službu, tj. jakýsi minimální rozsah poštovních služeb dostupný všem lidem za rozumnou cenu na celém území daného státu je pro svi̊j sociální charakter 
poskytován v mnoha zemích světa. Pokud jde o samotný postup liberalizace, je situace ve světě v porovnání s evropským poštovním sektorem různá. Např́iklad australský národní operátor má také část služeb vyhrazenou jen pro sebe, nicméně kromě listovních zásilek obsahuje i balíky včetně expresních zásilek. U listovních zásilek je pak limit vyhrazených služeb nastaven na 250 g a čtyřnásobek ceny základního tarifu. Americký národní operátor USPS, mimochodem největší poštovní operátor na světě, má také monopol na listovní i balíkové zásilky (kromě expresních zásilek). Listovní služby nesmí konkurenční firmy provozovat v oblasti pod 350 gramů a za méně, než činí šestinásobek základního tarifu. Mnohem liberálnější situace existuje $\mathrm{v}$ Japonsku, kde je poštovní trh plně otevřen konkurenci již od roku 2002. Do té doby používali Japonci k financování univerzální služby mechanizmus vyhrazených služeb národnímu poštovnímu operátorovi.

\section{Závěr}

Evropská unie má v problematice liberalizace poštovního trhu jasno. Poslední směrnice 2008/6/EC jasně stanovila, že od 1. ledna 2013 nebude jediná členská země využívat dosavadních poštovních monopolů a poštovní sektor EU bude otevřen zcela konkurenci. Hlavní přínos by pak měl směřovat k zákazníkům, pro které může být liberalizovaný trh prospěšný hlavně v oblasti vyšší kvality a rozsahu služeb. Liberalizovaný trh samozřejmě otevírá brány hlavně konkurenčním firmám, které se už na oblast do této doby vyhrazených služeb doslova třesou. Mnoho diskuzí se zatím vede na půdě Evropského parlamentu ohledně financování univerzální služby, kterou je potřeba zachovat v dostačující míré. Po ztrátě monopolů poskytovatelů univerzální služby to však nebude lehký úkol. V dohledné době je potřeba tento klíčový problém vyřešit. Plná liberalizace by měla být v konečném důsledku nástrojem pro uplatňování tržních sil a rozvoje konkurence v oblasti poštovních služeb, a tím i nastavením rovných podmínek na trhu.

\section{Literatura}

[1] ŠVADLENKA, L., ROTH, J. Problematika univerzální poštovní služby. Elektronický časopis Katedry spojov Žilinské univerzity: Pošta, telekomunikácie a elektronický obchod. 2008, s. 59 - 64. Dostupný z WWW: <http://ks.utc.sk/casopis/pdf/II2008/ svadlenka_roth.pdf $>$. ISSN 1336-8281.

[2] ŠVADLENKA, L., ROTH, J. Právní rámec sektoru poštovních služeb EU a ČR. Perner's Contacts: Elektronický odborný časopis o technologii, technice a logistice $v$ dopravé. 2008, s. 73 - 79. Dostupný z WWW: < http://pernerscontacts.upce.cz/10_2008/ Svadlenka_Roth.pdf>. ISSN 1801-674X.

[3] ŠVADLENKA, L. Tajemství evropských liberalizací. Direct marketing : Společná př́loha měsičníku Trend Marketing a týdeníku Marketing \& Media, 2008, č. 4, s. 22-23. ISSN1212-9496.

[4] LIJN, N. et al. Main developments in the European postal sector (2006 - 2008) - Final report. Ecorys [online]. Rotterdam, 2008 [cit. 2009-02-22]. Dostupný z WWW: <http://ec.europa.eu/internal_market/post/doc/studies/2008-ecorys-final_en.pdf>

[5] LIJN, N. et al. Main developments in the European postal sector (2006 - 2008) - Country sheet summaries. Ecorys [online]. Rotterdam, 2008 [cit. 2009-02-22]. Dostupný z WWW: $<$ http://ec.europa.eu/internal_market/post/doc/studies/2008country_sheet_ summaries.pdf> 
[6] ČOREJOVÁ, T., MADLEŇÁKOVÁ, L. K niektorým otázkam vývoja na poštových trhoch. In: Sborník př́spěvkiu z mezinárodni vědecké konference "Podniky v podminkách procesu globalizace a integrace", 2004. s. 19-23.

[7] MADLEŇÁK, R., MADLEŇÁKOVÁ, L. The postal market analysis in Europe, In: Studies of Faculty of operation and economics of transport and communications of University of Žilina. s. 117-122.

[8] SMĚRNICE 97/67/ES o společných pravidlech pro rozvoj vnitřního trhu poštovních služeb Společenství a zvyšování kvality služby. 